\title{
Oral Lichen Planus: A Clinical and Morphometric Study of Oral Lesions in Relation to Clinical Presentation
}

\author{
Juan SEOANE \\ María Amparo ROMERO \\ Pablo VARELA-CENTELLES \\ Pedro DIZ-DIOS \\ María José GARCIA-POLA \\ Stomatology Department, School of Medicine and Dentistry, University of Santiago de Compostela, \\ Santiago de Compostela, Spain
}

\begin{abstract}
Oral lichen planus (OLP) is a chronic inflammatory disease with different clinical presentations that can be classified as reticular or atrophic-erosive. Sixty-two OLP patients were studied to evaluate the clinical-pathologic characteristics of their OLP lesions and to investigate possible differences in their biological behavior. The most common clinical presentation was the reticular type (62.9\% vs $37.1 \%$ ). Atrophic-erosive presentations showed significantly longer evolution (chi square $=4.454 ; \mathrm{p}=0.049$ ), more extensive lesions (chi square=16.211; $\mathrm{p}=0.000$ ) and more sites affected than reticular ones (chi square=10.048; $\mathrm{p}=0.002$ ). Atrophic-erosive OLP was more frequently found on the tongue, gingiva and floor of the mouth. No statistically significant differences could be identified between reticular and atrophic-erosive clinical presentations in terms of age, sex, tobacco habit, plasma cortisol level and depth of inflammatory infiltrate. We concluded that the classification of OLP lesions as reticular vs atrophic-erosive is a simple, easy to use classification that can identify clinical presentations with different biological behavior.
\end{abstract}

Key Words: oral lichen planus, clinical classification, morphometry.

\section{INTRODUCTION}

Oral lichen planus is a chronic inflammatory disease of immune origin whose etiopathogenesis has not been completely disclosed. Factors such as stress, genetic background, certain dental materials, several drugs, infectious agents or an association with autoimmune disorders have been involved $(1,2)$. Lichen planus is a fairly common mucocutaneous disease affecting $0.1-4 \%$ of individuals, depending on the population studied (1-3).

It is often questioned whether malignant transformations occur on OLP lesions or on epithelial dysplasias of lichenoid appearance (4).

OLP eruptions usually have a distinct clinical morphology and a characteristic distribution, but OLP may also present a confusing array of patterns and form
(1). Andreasen's classical classification consisting of reticular, papular, plaque, atrophic, bullous and erosive forms (5) was simplified by other authors who consider only reticular, atrophic and erosive clinical presentations (6).

In this study, OLP lesions were divided into two groups: those with mainly atrophic-erosive presentations and those with reticular lesions. This study assessed the clinical-pathologic characteristics of both groups of lesions and also investigated the existence of differences in biological behavior between these groups.

\section{MATERIAL AND METHODS}

Sixty-two randomly selected patients were recruited from a series of 95 OLP patients diagnosed at the Bay of Biscay Navy Hospital Stomatology Service 
(Galicia, Spain), between January 1998 and October 1999. Exclusion criteria were: patients not willing to enter the study and suspicion of drug-induced lichenoid reaction. OLP diagnosis was made according to Andreasen's clinical and pathologic criteria (5). Mean age of the patients was $63.5 \pm 14.49$ years (males $=48.4 \%$, females $=51.6 \%$ ).

The sample was divided in two groups according to the clinical presentation of the lesions: patients with exclusively reticular lesions (white lesions), and patients with atrophic-erosive lesions (red lesions) with or without associated reticular lesions (7). Age, sex, extension of the lesions, site, time of evolution, and number of sites affected were recorded for each patient.

Plasma cortisol could be determined in 40 patients and 24-h urine cortisol was determined in 31 patients. Two consecutive surface involvement grades were considered: $1=$ a single or two affected sites; $2=$ three or more sites.

The oral biopsy specimens were routinely processed for histologic study after fixation in $10 \%$ buffered formalin and stained with hematoxylin-eosin. A morphometric study was also done at a workstation consisting of an Olympus CX-40 microscope connected to a videocamera (TK-C621-EG) and an image analyzer (microimage 3.0 Fosterfinley Pc-image).

In order to avoid histological differences due to the different origin of the samples, only specimens obtained from the buccal mucosa were used for morphometric analysis. Only those areas whose sections included both epithelium and underlying connective tissue were considered.

Each quantitative evaluation included the depth of the inflammatory infiltration within the submucosa measured from the lower limit of the epithelium. The density of the inflammatory infiltrate was evaluated by two independent observers who assessed 29 specimens using a previously validated scale (8) consisting of two degrees: light, and moderate/severe. The final value allocated to each case was the average of at least five measurements.

Statistical analysis was performed with a SPSS+ (8.0) statistical package. The Student t-test was used to compare quantitative variables and the chi square test for qualitative parameters. The significance level chosen for all tests was $5 \%$. The association measurement used was the odds ratio (OR) with a confidence interval of $95 \%$.

\section{RESULTS}

The reticular clinical presentation (white lesion) was the most frequent in this series $(n=39 ; 62.9 \%)$, whereas red lesions (atrophic-erosive presentations) were found in 23 patients (37.1\%). The most frequent site of OLP lesions was the buccal mucosa (48 cases; $78.7 \%$ ), where bilateral lesions were identified in 33 patients $(53.2 \%$ of the sample). The tongue was the second most frequent site (20 cases; $32.3 \%$ ), followed by gingiva (18 cases; $29 \%$ ), lips ( 6 cases; $9.7 \%$ ), palate ( 5 cases; $8.1 \%$ ) and floor of the mouth ( 3 cases; $4.8 \%$ ).

Average plasma cortisol was $19.2 \pm 7.1 \mu \mathrm{g} / \mathrm{dl}$ and $24-\mathrm{h}$ urine cortisol was $137.1 \pm 156 \mu \mathrm{g} / \mathrm{dl}$. Nine cases $(31 \%)$ showed a light density inflammatory infiltrate, and this was moderate in 11 cases $(37.9 \%)$ and severe in 9 patients (31\%). The mean depth of the inflammatory infiltrate was $261.5 \pm 144.9 \mu \mathrm{m}$.

When the group of patients with white lesions was compared with patients with red lesions, no statistically significant differences were found in terms of age $(\mathrm{t}=-1.130 ; \mathrm{p}=0.263)$, sex (chi square $=0.210$; $\mathrm{p}=0.793$ ) or tobacco habit (chi square $=2.705 ; \mathrm{p}=0.184$ ). Atrophic-erosive lesions showed a significantly shorter period of evolution (chi square $=4.454 ; \mathrm{p}=0.049$ ), larger lesions (chi square $=16.211 ; \mathrm{p}=0.000$ ) and a higher number of sites affected (chi square $=10.048 ; \mathrm{p}=0.002$ )

Table 1. Differential features of reticular and atropic-erosive OLP.

\begin{tabular}{lrrr}
\hline Variable & Reticular & Atrophic-Erosive $\begin{array}{c}\text { Odds Ratio } \\
(95 \% \mathrm{CI})\end{array}$ \\
& & & \\
& & & \\
Sex & & & \\
$\quad$ Male & $18(46.2 \%)$ & $12(52.2 \%)$ & 0.78 \\
$\quad$ Female & $21(53.8 \%)$ & $11(47.8 \%)$ & $(0.28-2.20)$ \\
$\quad$ Time of evolution & & & \\
$\quad<6$ months & $12(52.2 \%)$ & $3(18.8 \%)$ & 4.72 \\
$\quad>6$ months & $11(47.8 \%)$ & $13(81.2 \%)$ & $(1.05-21.15)$ \\
Smoker & & & \\
$\quad$ Yes & $11(28.9 \%)$ & $2(10.0 \%)$ & 3.66 \\
$\quad$ No & $27(71.1 \%)$ & $18(90.0 \%)$ & $(0.72-18.53)$ \\
Extension & & & \\
$\quad$ Light & $28(71.8 \%)$ & $4(18.2 \%)$ & 11.45 \\
$\quad$ Moderate/Severe & $11(28.2 \%)$ & $18(81.8 \%)$ & $(3.15-41.54)$ \\
Number of sites & & & \\
$\quad \leq 2$ & $34(87.2 \%)$ & $11(50.0 \%)$ & 6.80 \\
$\quad \geq 3$ & $5(12.8 \%)$ & $11(50.0 \%)$ & $(1.93-23.89)$ \\
\hline
\end{tabular}


(Table 1).

The prevalence of atrophic-erosive lesions was greater on the tongue (chi square $=18.177 ; \mathrm{p}=0.000$ ), gingiva (chi square $=9.504 ; \mathrm{p}=0.003$ ) or the floor of the mouth (chi square $=5.346 ; \mathrm{p}=0.047$ ), whereas reticular lesions were more prevalent on the buccal mucosa ( $86.8 \%$ vs $65.2 \%$ red lesions), However, this difference was not significant (chi square $=3.995 ; \mathrm{p}=0.059$ ). When other oral cavity regions were analyzed, no statistically significant differences could be found between the OLP groups (Table 2).

The mean value of plasma cortisol in patients with reticular OLP lesions was $18.4 \pm 7.2 \mu \mathrm{g} / \mathrm{dl}$ and $20.4 \pm 6.8 \mu \mathrm{g} / \mathrm{dl}$ in patients with atrophic-erosive lesions $(t=0.84 ; \mathrm{p}=0.40)$. No statistically significant differences were found in terms of urine cortisol either $(121.3 \pm 74.8 \mu \mathrm{g} / \mathrm{dl}$ in white OLP; $160.2 \pm 231.2 \mu \mathrm{g} / \mathrm{dl}$ in red OLP; $\mathrm{t}=0.68 ; \mathrm{p}=0.49$ ).

The depth of the inflammatory infiltrate in white lichens $(278.43 \pm 148.81 \mu \mathrm{m})$ was not significantly different $(\mathrm{p}<0.05)$ from that of red lichens $(217.31 \pm$ $133.15 \mu \mathrm{m})$. When the density of the inflammatory infiltrate was grouped as type 1 being light and type 2 being moderate/severe, type 2 reached greater depths than those of minor cellular density $(t=3.954 ; \mathrm{p}<0.05)$.

Table 2. Different sites for reticular and atrophic-erosive OLP.

\begin{tabular}{|c|c|c|c|}
\hline Site & Reticular & Atrophic-Erosive & $\begin{array}{l}\text { Odds Ratio } \\
(95 \% \mathrm{CI})\end{array}$ \\
\hline \multicolumn{4}{|l|}{ Tongue } \\
\hline Yes & $5(12.8 \%)$ & $15(65.2 \%)$ & 0.07 \\
\hline No & $34(87.2 \%)$ & $8(34.8 \%)$ & $(0.02-0.28)$ \\
\hline \multicolumn{4}{|c|}{ Buccal Mucosa } \\
\hline Yes & $33(86.8 \%)$ & $15(65.2 \%)$ & 3.52 \\
\hline No & $5(13.2 \%)$ & $8(34.8 \%)$ & $(0.98-12.57)$ \\
\hline \multicolumn{4}{|c|}{ Gingiva } \\
\hline Yes & $6(15.4 \%)$ & $12(52.2 \%)$ & 0.16 \\
\hline No & $33(84.6 \%)$ & $11(47.8 \%)$ & $(0.05-0.55)$ \\
\hline \multicolumn{4}{|l|}{ Palate } \\
\hline Yes & $2(5.1 \%)$ & $3(13.0 \%)$ & 0.36 \\
\hline No & $37(94.9 \%)$ & $20(87.0 \%)$ & $(0.05-2.33)$ \\
\hline \multicolumn{4}{|c|}{ Floor of mouth } \\
\hline Yes & 0 & $3(13.0 \%)$ & 2.95 \\
\hline No & $39(100 \%)$ & $20(87.0 \%)$ & $(2.06-4.21)$ \\
\hline \multicolumn{4}{|l|}{ Lip } \\
\hline Yes & $2(5.1 \%)$ & $4(17.4 \%)$ & 0.25 \\
\hline No & $37(94.9 \%)$ & $19(82.6 \%)$ & $(0.04-1.53)$ \\
\hline
\end{tabular}

\section{DISCUSSION}

OLP is generally a disease of the middle-aged and elderly $(1,2)$. There is a female predominance ranging from $54 \%$ to $65 \%$ (9). Our findings are in agreement with others that OLP is more frequently found on the buccal mucosa, tongue and gingiva and rarely on the palate, lip mucosa and floor of the mouth $(5,6)$. Average plasma and 24-h urine cortisol levels were within normal range, which does not support the hypothesis that environmental factors have an influence on the neuroendocrine system through cortisol levels and lymphocyte populations in OLP patients (10).

The atrophic-erosive clinical form is composed of a group of lesions characterized by an epithelial thinning that can induce erosion of the oral mucosa with a frequency of $33-72 \%(6,7,11,12)$.

An association of atrophic clinical presentations with age older than 60 years has been suggested (11). In the present study, patients with atrophic-erosive lesions showed a higher mean age than those with reticular lesions $(66.2 \%$ vs $61.9 \%)$. This trend was statistically significant in other studies (13).

There is no agreement on the influence of tobacco habit on OLP. The proportion of smokers ranges from $15 \%$ to $93 \%$ (14), although no statistically significant associations between OLP and tobacco could be proved (6). Our results showed that a tobacco habit did not favor a particular clinical presentation of OLP.

Lichen planus tends to follow an evolution that comprises periods of remission and exacerbation on a chronic course that might lead to malignant transformation $(15,16)$. As to the type of OLP most likely to undergo malignant change, several authors have reported atrophic/ulcerative/erosive OLP lesions with the greatest tendency for malignant development. In some of these studies, most carcinomas developed in either the tongue or gingiva $(6,15,16)$.

The mean evolution time of OLP is usually longer than a year, and a positive correlation between extension of the lesion and time of evolution has been established (7). Our results suggested that for atrophicerosive clinical lesions, a longer period of evolution would induce more extensive lesions and a higher number of sites affected, preferably on the tongue, gingiva and floor of the mouth. No differences could be identified in plasma or urine cortisol levels between 
patients with different clinical presentations of OLP. These results do not support Chiapelli's model of psychoneuroendocrine interaction suggested for this disease that includes those psychological disorders able to alter cortisol levels, increase CD4RO subpopulations and lead to a more aggresive OLP presentation (10).

Previous research failed to associate extension of OLP and intensity of inflammatory infiltrate (8). Our results seem to confirm that the severity of the inflammatory infiltrate is independent from the clinical presentation of OLP $(17,18)$. This finding suggests that epithelial atrophy and the presence of ulcerations are exclusively a consequence of qualitative aspects of the inflammatory infiltrate.

Several OLP classifications have been proposed with different degrees of complexity (5-7). However, the classification of reticular and atrophic-erosive OLP is easy to use by clinicians and distinguishes clinical forms with different biologic behaviors and seems to be able to identify lichens at higher risk of malignant transformation and more frequently associated with hepatitis $C$ virus infection $(6,15,16,19)$.

\section{RESUMO}

O liquen plano oral (LPO) é uma doença inflamatória crónica com diferentes apresentações clínicas que podem ser classificadas como reticuladas ou atrófico-erosivas. Sessenta e dois pacientes com LPO foram estudados para avalidar as características clínicas/ patológicas das suas lesões de LPO e investigar possíveis diferenças no seu comportamento biológico. A forma clínica mais comum foi a de tipo reticular $(62,9 \%$ vs $37,1 \%)$. As formas atrófico-erosivas apresentaram um tempo de evolução significativamente maior (chi quadrado $=4,454 ; \mathrm{p}=0,049$ ), lesões mais extensas (chi quadrado $=16,211 ; \mathrm{p}=0,000$ ) e afetaram a mais localizações em comparação com as lesões reticulares (chi quadrado=10,048; $\mathrm{p}=0,002$ ). A forma atrófico-erosiva de LPO foi encontrada mais frequentemente na língua, gengiva e pavimento da boca. Não foram encontradas diferenças significativas entre as formas reticular e atrófico-erosivas em termos de idade, sexo, hábito tabágico, niveis plasmáticos de cortisol e profundidade de infiltrado inflamatório. Concluímos que a classificaçao de lesões de LPO como reticular vs atróficoerosivo é uma classificaçao simples e facil de usar, que pode identificar apresentações clínicas com diferentes comportamentos biológicos.

\section{REFERENCES}

1. Scully C, Beyli M, Ferreiro M, Ficarra G, Gill Y, Griffiths M, Holmstrup P, Mutlu S, Porter S, Wray D. Update on oral lichen planus: Etiopathogenesis and management. Crit Rev Oral Biol Med 1998;9:86-122.

2. Sugerman PB, Savage NW. Oral lichen planus: causes, diagnosis and management. Aust Dent J 2002;47:290-297.

3. Sugerman PB, Savage NW, Walsh LJ, Zhao ZZ, Zhou XJ, Khan A, Seymour GJ, Bigby M. The pathogenesis of oral lichen planus. Crit Rev Oral Biol Med 2002;13:350-365.

4. Krutchoff DJ, Eisemberg E. Lichenoid dysplasia. A distinct histopathologic entity. Oral Surg Oral Med Oral Pathol 1985;60:308315.

5. Andreasen JO. Oral lichen planus. I. A clinical evaluation of 115 cases. Oral Surg Oral Med Oral Pathol 1968;25:31-42.

6. Silverman Jr S, Gorksy M, Lozada-Nur F. A prospective followup of 570 patients with oral lichen planus: persistence, remission, and malignant association. Oral Surg Oral Med Oral Pathol 1985;60:30-34.

7. Bagan Sebastián JV, Milián Masanet MA, Peñarrocha Diago M, Jiménez Y. A clinical study of 205 patients with oral lichen planus. J Oral Maxillofac Surg 1992;50:116-118.

8. Bagán JV, Aguirre JM, Del Olmo JA, Milián A, Peñarrocha M, Rodrigo JM, Cardona F. Oral lichen planus and chronic liver disease: A clinical and morphometric study of the oral lesions in relation to transaminase elevation. Oral Surg Oral Med Oral Pathol 1994;78:337-342.

9. Scully C, El-Kom M. Lichen planus: review and update on pathogenesis. J Oral Pathol 1985;14:431-458.

10. Chiapelli F, Kung MA, Nguyen P, Villanueva P, Arash E, Eversole LR. Cellular inmune correlates of clinical severity in oral lichen planus: preliminary association with mood states. Oral Dis 1997;3:64-70.

11. Thorn JJ, Holmstrup P, Rindum J, Pindborg JJ. Course of various clinical forms of oral lichen planus. A prospective follow-up study of 611 patients. J Oral Pathol 1988;17:213-218.

12. Silverman Jr S, Gorsky M, Lozada Nur F, Giannotti K. A prospective study of findings and management in 214 patients with oral lichen planus. Oral Surg 1991;72:665-670.

13. Bagan JV, Donat JS, Peñarrocha M, Milian MA, Sanchis JM. Oral lichen planus and diabetes mellitus. A clinico-pathological study. Bull Group Int Rech Sci Stomatol et Odontol 1993;36:3-6.

14. Boyd AS, Neldner KH. Lichen planus. J Am Acad Dermatol 1991;25:593-612.

15. Mignogna MD, Lo Russo L, Fedele S, Ruoppo E, Califano L, Lo Muzio L. Clinical behaviour of malignant transforming oral lichen planus. Eur J Surg Oncol 2002;28:838-843.

16. Barnard N, Scully C, Evenson J, Cunningham S, Porter S. Oral cancer development in patients with oral lichen planus. J Oral Pathol Med 1993;22:421-424.

17. Bagan JV, Aguirre JM, Milián M, Peñarrocha M, García-Pola MJ. Etude morphométrique dans 74 cas de lichen plan oral. Rev Stomatol Chir Maxillofac 1991;92:265-268.

18. Garcia-Pola MJ, Anitua-Roldan MJ, García-Martin JM, González-García M. Análisis morfométrico del infiltrado inflamatorio celular del liquen plano oral. Av Odontoestomatol 2001;17:133-137.

19. Pilli M, Penna A, Zerbini A, Vesconi P, Manfredi M, Negro F, Carrozo M, Mori C, Giuberti T, Ferrari C, Missale G. Oral lichen planus pathogenesis: A role for the HCV-specific cellular immune response. Hepatology 2002;36:1446-1452. 